\title{
CITIZEN JOURNALISM DALAM MENANGGULANGI MASALAH SOSIAL
}

\author{
${ }^{1)}$ Wulan Purnama Sari, ${ }^{2}$ Sinta Paramita \\ ${ }^{2,)}$ Fakultas Ilmu Komunikasi, Universitas Tarumanegara \\ wulanp@fikom.untar.ac.id, sintap@fikom.untar.ac.id
}

\begin{abstract}
Abstrak
Semakin meningkatnya trend sosial media dan smart phone menimbulkan sebuah trend baru dalam masyarakat, yaitu trend citizen journalism. Kemudahan akses internet dan teknologi menjadikan setiap orang dapat menjadi reporter dimanapun dan kapanpun. Hal ini menimbulkan masalah sosial baru karena dengan adanya segala kemudahan ini, setiap orang menjadi kurang peka dan kurang peduli pada etika dalam melakukan citizen journalism. Seperti foto dan kejadian apa yang layak untuk diunggah di sosial media. Keresehan ini juga muncul dikalangan para tenaga pendidik yang mengkhawatirkan peserta didiknya, yang merupakan generasi muda yang sangat dekat dengan sosial media dan rentan terhadap masalah etika ini. terlebih bagi mitra yang merupakan lembaga pendidikan yang khusus untuk mendidik para calon guru agama. Peserta didik dari STAKN Manado yang juga merupakan calon guru agama dididik untuk mengikuti nilainilai yang diajarkan dalam agama sedangkan terkadang nilai tersebut bertentangan dengan situasi dan kondisi masa kini yang menjadikan sulit untuk dipatuhi. Terlebih bagi para generasi muda gereja yang sangat rentan terhadap nilai-nilai dunia yang dianggap modern dan mengikuti zaman ini. Untuk menyelesaikan masalah ini, tim mengusulkan untuk melakukan kegiatan ceramah dan penyuluhan untuk meningkatkan pemahaman dan kesadaran mahasiswa dari STAKN Manado mengenai fungsi dan etika dari citizen journalism.
\end{abstract}

Kata Kunci: Citizen Journalism, Etika, Manado, Nilai Agama, Sosial.

\begin{abstract}
The increasing trend of social media and smart phone cause a new trend in society, citizen journalism trend. The ease of internet access and technology makes everyone can be a reporter wherever and whenever. This creates a new social problem because with all these conveniences, everyone becomes less sensitive and less concerned about ethics in conducting citizen journalism. For example, what kind of photos and events that are eligible to be uploaded in social media. This healthiness also arises among educators who are concerned about their students, who are young people who are very close to social media and vulnerable to this ethical issues. Especially for team's partner who are specialized in educational institutions to educate potential religion teachers. Students of STAKN Manado who are also candidates for religious teachers are educated to follow the values taught in religion while sometimes the value is contrary to the present situation and conditions that make it difficult to obey. Especially for the younger generation of the church is very vulnerable to the values of the world that is considered modern and follow this age. To solve this problem, the team proposes to conduct lectures and extension activities to improve students' understanding and awareness of STAKN Manado regarding the function and ethics of citizen journalism.
\end{abstract}

Keywords: Citizen Journalism, Ethics, Manado, Religion values, Social 


\section{PENDAHULUAN}

Euphoria kebebasan mengeluarkan pendapat setelah berakhirnya Rezim Orde Baru bulan Mei 1998 diikuti penggunaan smartphone dengan menggunakan kamera yang semakin meluas oleh masyarakat Indonesia membuat masyarakat berani untuk melontarkan temuan, ide ataupun pikirannya melalui blog maupun media sosial seperti melalui Path, twitter, Facebook ataupun Instagram.

Fenomena tersebut tak ayal melahirkan bentuk baru dari jurnalisme yaitu citizen journalism atau jurnalisme warga. Jurnalisme warga didasari oleh gagasan bahwa masyarakat yang tidak mengalami pelatihan maupun pendidikan jurnalisme profesional dapat memanfaatkan peralatan teknologi modern dan internet global untuk berkreasi, melengkapi maupun memeriksa faktafakta yang diberitakan dalam media. Hal itu bisa dilakukan sendiri maupun berkolaborasi dengan yang lain. (Gani, n.d.). Secara bebas jurnalisme warga ini dapat diartikan sebagai sebuah kegiatan partisipasi aktif yang dilakukan oleh masyarakat dalam kegiatan pengumpulan, pelaporan sampai analisis dan penyampaian informasi dan berita.

Tidak dapat disangkal bahwa jurnalisme warga akan menjadi paradigma dan trend baru tentang bagaimana pembaca atau pemirsa membentuk informasi dan berita pada masa mendatang. Karena dalam aktifitas ini pada dasarnya masyarakatlah yang memainkan peran aktif dalam proses pengumpulan, pelaporan dan penyebaran berita dan informasi. Hal ini yang belakangan ini disebut sebagai alternatif dan bentuk aktivitas news gathering yang berfungsi di luar institusi media mainstream.

Untuk Indonesia perkembangan jurnalisme warga ini diawali dari liputan musibah tsunami yang terjadi di Aceh pada tanggal 26 Desember 2014. Liputan seorang warga dari atas rumahnya yang bertingkat tentang gelombang tsunami yang menerjang perumahan warga dan liputan lainnya dari seorang warga ketika gelombang tsunami menggulung mobil dan menerjang pertokoan di daerah sekitar Masjid Baiturahman tengah kota Banda Aceh mengalahkan berita yang dibuat oleh jurnalis professional.

Saat ini siapapun dapat menjadi jurnalis melaporkan hampir berbagai aspek yang terjadi dalam kehidupan sehari hari. Aspek ekonomi, budaya maupun politik semua dilaporkan. Karena pada dasarnya masyarakat Indonesia memiliki sifat suka berbagi. Mulai dari antrian orang disuatu tempat perbelanjaan, sebuah konser musik, kemacetan lalu lintas, agempa bumi di satu daerah, bencana gunung meletus, sampai pada kecelakaan lalu lintas, dll. Semua direkam lalu diunggah ke berbagai kanal sehingga seluruh dunia dapat melihatnya.

Jurnalisme media massa tentu saja diatur oleh kode etik bahwa sebuah berita yang layak tayang haruslah berimbang, harus melakukan cek ricek terhadap data-data yang bersifat sensitif dan mencakup cover both side. Mudahnya melakukan jurnalisme warga ini menimbulkan masalah sosial baru dalam masyarakat karena seringkali banyak berita atau informasi yang diungah warga seharusnya tidak layak untuk diunggah sehingga menimbulkan keresahan dalam masyarakat.

Tidak dapat dipungkiri selain dampak positif atas perkembang teknologi komunikasi dan informasi yang terus berkembang juga membawa dampak negatif. Salah satunya adalah hoax. Hoax dapat diartikan sebagai informasi yang tidak sesuai dengan faktanya, dengan tujuan agar orang dapat mempercayai informasi tersebut. Hoax 
kerap muncul di media sosial, hal ini karena pada media sosial tidak terdapat gate keeper seperti pada media massa, sehingga ribuan informasi dapat menyebar dengan langsung dan cepat setiap saatnya (Anisa, 2016). Lebih lanjut, Sebastian (2016) memaparkan Hoax sendiri sebenarnya sebuah kabar atau cerita bohong yang sengaja dibuat atau difabrikasi, seolah-olah kabar atau cerita tersebut benar adanya. Istilah hoax sendiri berasal dari abad ke-18 dari kata hocus, yang artinya mengecoh atau menipu. Kata hoax sendiri populer berbarengan dengan semakin mendunianya internet. Hoax atau cerita tipuan sebenarnya memiliki dua tujuan, pertama untuk sekedar lelucon yang biasanya beredar di kelompok terbatas, kemudian bertujuan jahat, sengaja difabrikasi untuk menipu atau mengecoh. Hoax mendapat momen besar, ketika media sosial menjadi sangat umum dan berkembang di zaman internet. Begitu masifnya hoax yang beredar, sehingga seringkali banyak orang terkecoh untuk mempercayainya, bahkan turut menjadi sarana penyebaran hoax.

Untuk meningkatkan kualiatas dari pemberitaan masyarakat agar terhindar dari berita Hoax tersebut maka edukasi mutlak diperlukan. Oleh karena itu Fakultas Ilmu Komunikasi (FIKom) Universitas Tarumanagara Jakarta (UNTAR) berencana untuk melaksanakan kegiatan pengabdian kepada masyarakat, dengan tema: Citizen Journalism Dalam Menanggulangi Masalah Sosial di STAKN Manado akan melibatkan dosen dilingkungan FIKom UNTAR.

Setelah diskusi dengan pihak mitra, maka diketahui bahwa masalah utama yang menjadi prioritas dan harus diselesaikan adalah banyaknya masalah yang timbul di dalam dan di luar lembaga pendidikan akibat kurangnya pemahaman akan fungsi, peran, dan pemanfaatan dari sosial media dan teknologi. Hal ini menyebabkan masalah terkait dengan trend citizen journalism sekarang ini, dimana masyarakat menjadi kurang peka akan etika dalam melaksanakan citizen journalism, sehingga menimbulkan keresahan di dunia pendidikan dan masyarakat secara luas.

Kurangnya kepekaan dalam hal etika ini tidak hanya terjaid dari pihak masyarakat secara umum yang menjadi pelaku citizen journalism, tapi juga dari pihak wartawan yang seharusnya lebih memahami tentang etika jurnalisme itu sendiri. Dewan Pers pernah melakukan survei terkait literasi wartawan terhadap kode etik. Survei ini dilakukan pada tahun 2011 dengan melibatkan 1.200 responden dari 33 provinsi di Indonesia dengan menggunakan metode kuantitatif. Hasil temuan dari survei tersebut menyebutkan bahwa sebanyak 10 persen dari wartawan yang disurvei belum pernah sama sekali membaca kode etik jurnalistik, 42 persen pernah membaca seluruh kode etik tersebut, dan 48 persen membacanya sebagian. Selain itu, pihak yang diadukan ke dewan pers pada tahun 2012, antara lain wartawan media cetak sebanyak 328 kali $(65,60$ persen), wartawan media online sebanyak 90 kali (18 persen), wartawan media elektronik sebanyak 36 kali $(7,2$ persen). (Marketeers, 2012)

Terkait masalah etika ini pemerintah juga melakukan upayaupaya untuk menanggulangi, ditambah lagi dengan perkembangan media online yang sangat pesat. Upaya ini salah satunya dilakukan dengan cara mengesahkan UU ITE dan sebagai dampaknya Menkominfo telah melakukan pemblokiran terhadap situs-situs yang dianggap konten atau isinya menyalahi regulasi yang berlaku. Sejauh ini situs yang sudah diblokir oleh 
Menkominfo sebanyak hamper 800.000 situs. (Hartik,2017)

Masalah etika ini juga menimbulkan dampak negatif bagi penggunaan new media atau internet. Paramita, et al (2015) menuliskan bahwa penggunaan new media dapat menimbulkan dampat negatif khususnya bagi anak muda, karenanya diperlukan kesadaran dan kehatian-hatian dalam menggunakan internet tersebut.

Berdasarkan hasil pertimbangan atau justifikasi yang dibuat atas dasar diskusi bersama dengan mitra, peneliti memutuskan untuk mengadakan kegiatan Pengabdian Kepada Masyarakat dengan tema "Citizen Journalism Dalam Menanggulangi Masalah Sosial"

\section{METODE PELAKSANAAN}

Pada bagian pendahuluan telah dijelaskan mengenai analisis situasi dan rumusan permasalah yang dihadapi oleh mitra. Berdasarkan hal tersebut, tim pengusul melaksanakan kegiatan PKM ini dengan metode observasi, wawancara mendalam dengan mitra khalayak, dan juga mengadakan penyuluhan kepada mitra khalayak. Perlu diketahui bahwa mitra dalam kegiatan PKM ini adalah STAKN Manado dan sasaran dari kegiatan PKM ini adalah peserta didik atau mahasiswa/mahasiswi dari STAKN Manado, dimana ketika lulus nanti para peserta didik mayoritas akan menjadi guru agama, dosen, atau bahkan pendeta.

Kegiatan PKM ini akan dilaksanakan dalam beberapa tahap, pertama adalah melakukan audiensi dengan pihak mitra. Dari tahap ini diperoleh analisis situasi dan juga permasalahan yang dihadapi oleh mitra. Tahap kedua adalah melakukan diskusi mengenai solusi yang tepat atas permasalahan tersebut bersama dengan mitra. Kemudian solusi yang diputuskan dituangkan dalam bentuk proposal kegiatan PKM yang akan dilaksanakan oleh tim dengan bantuan dari mitra. Dalam hal ini, mitra akan memberikan bantuan berupa penyediaan fasilitas tempat untuk mengadakan kegiatan penyuluhan. Sedangkan materi dan perlengkapan akan disiapkan oleh tim pengusul dari FIKom UNTAR. Terkait waktu dan pelaksanaan dari kegiatan PKM diputuskan bersama dengan mitra. Kemudian peserta dari kegiatan PKM dalam bentuk ceramah dan penyuluhan merupakan para peserta didik atau mahasiswa/mahasiswi dari STAKN Manado yang merupakan mitra khalayak dalam kegiatan pengabdian ini. Melalui kegiatan ceramah dan penyuluhan ini, tim akan melakukan interaksi langsung dengan khalayak sasaran dan khalayak sasaran dapat dengan bebas bertanya dan mengemukakan opini selama kegiatan PKM berlangsung.

Tahap ketiga adalah melakukan evaluasi dan monitoring atas kegiatan PKM ini, apakah solusi yang diberikan berhasil mencapai tujuan dan memiliki manfaat bagi mitra atau tidak. Kegiatan evaluasi dan monitoring akan dilakukan dengan berkerjasama dengan tenaga pendidik dari STAKN Manado, karena tim tidak dapat berada di lokasi dalam waktu terus-menerus. Berdasarkan hasil evaluasi dan monitoring ini kemudian tim dan mitra akan melakukan diskusi kembali apakah perlu diadakan kegiatan lanjutan atau tidak, dan apakah solusi yang diberikan efektif untuk menghadapi masalah yang dihadapi oleh mitra.

Hasil dari kegiatan PKM ini juga akan dikirimkan kepada pihak mitra untuk menjadi bahan referensi bagi mitra dalam mengembangkan kualitas organisasinya. Selain itu, tim pengusul juga akan memberikan hasil publikasi dari kegiatan ini sebagai bentuk penghargaan kepada pihak mitra atas kerjasama dan partisipasinya dalam 
acara Pengabdian Kepada Masyarakat ini.

\section{HASIL DAN PEMBAHASAN}

Berdasarkan hasil audiensi dengan mitra didapatkan atau diperoleh analisis situasi dan rumusan permasalahan yang telah dikemukakan pada bab pendahuluan. Permasalahan pokok utama yang dihadapi oleh mitra terkait adanya keresahan yang dimiliki oleh mitra terhadap anak peserta didiknya mengenai perkembangan trend di masyarakat sekarang ini mengenai penggunaan media sosial, internet, dan teknologi komunikasi yang semakin canggih. Pihak mitra khawatir bila para anak didiknya yang merupakan generasi muda dan sekaligus calon dari guru agama dan pendeta ini akan melupakan atau meninggalkan nilai-nilai ajaran agama dan mengikuti nilai-nilai modern yang seringkali tidak sesuai dengan ajaran nilai agama.

Atas dasar permasalahan tersebut tim akhirnya mengambil tema pengabdian tentang "Citizen Journalism Dalam Menanggulangi Masalah Sosial". Kegiatan PKM dilakukan dalam bentuk ceramah dan penyuluhan tentang citizen journalism dan etika dalam penerapannya. Materi yang disusun dimulai dengan adanya Undang-Undang ITE No. 11 tahun 2008, dan data mengenai berapa jumlah netizen yang telah terkena kasus hukum sejak adanya undang-undang tersebut. Kemudian penyampaian inti materi mengenai tips tentang bagaimana seharusnya menggunakan sosial media dan etika dalam bersosial media sendiri, seperti hal apa saja yang dapat di share atau yang sebaiknya tidak di share.

Kegiatan PKM ini diharapkan dapat membantu menyelesaikan masalah utama yang dihadapi oleh mitra. Selain itu, kegiatan PKM ini juga diharapkan menambah wawasan dan kesadaran para mahasiswa/mahasiswi sebagai generasi muda tentang etika dalam melakukan citizen journalism. Kemudian juga menyadari dampak atau akibat yang dapat timbul bila etika tersebut tidak diikuti atau dipatuhi, serta permasalahan apa saja yang dapat timbul terkait dengan citizen journalism dan penggunakan teknologi komunikasi yang semakin canggih.

Pelaksanaan kegiatan PKM dilakukan pada tanggal 04 April - 07 April, sesi ceramah dan penyuluhan dilakukan pada tanggal 05 April sesuai dengan hasil diskusi dengan pihak mitra. Lokasi dan tempat disediakan oleh mitra, yaitu bertempat di Aula STAKN Manado. Kegiatan ini diikuti oleh seluruh mahasiswa/mahasiswi dari STAKN Manado. Kedatangan tim disambut oleh Ketua STAKN Manado Dr. Jeane Marie Tulung, S.Th, M.Pd; dan dosen di STAKN Manado Pdt Dr Johan Nicolaas Gara, STh, MA yang akan menjadi moderator dalam acara penyuluhan dan ceramah yang dibuat dalam bentuk kuliah umum.

Kegiatan atau acara PKM dimulai dengan sesi pertama berupa pemberian ceramah dan materi oleh tim pengabdian dari Fikom Untar. Materi yang diberikan Tim Fikom Untar mem-bahas tentang Etika Journalism Netizen. Isi materi tersebut diawali oleh kesadar-an akan larangan dalam peraturan perundangundangan yang mengatur dalam pemanfaatan teknologi. Seperti yang dijelaskan dalam Undang-Undang Informasi dan Transaksi Elektornik (UU ITE) No:11 2008 pada pasal 27 menjelaskan bahwa konten kesusilaan, perjudian, penghinaan dan pencemaran nama baik dan pemerasan atau pun ancaman dapat dikenakan hukum pidana penjara paling lama 6 (enam) tahun dan/atau denda paling banyak Rp 1.000.000.000,00 (satu miliar rupiah). 
Tidak hanya sampai disitu UU ITE No. 112008 pada pasal 28 menekankan bahwa melarang menyebarkan berita bohong dan menyesatkan yang mengakibatkan kerugian konsumen dalam Transaksi Elektronik. Setiap orang yang dengan sengaja dan tanpa hak menyebarkan informasi yang ditujukan untuk menimbulkan rasa kebencian atau permusuhan individu dan/atau kelompok masyarakat tertentu berdasarkan atas suku, agama, ras, dan antargolongan (SARA). Jika melanggar akan mendapatkan pidana penjara paling lama 6 (enam) tahun dan/atau denda paling banyak Rp 1.000.000.000,00 (satu miliar rupiah).

Tim Fikom Untar lebih lanjut memaparkan data sepanjang 2016 terjadi peningkatan pelaporan kepada kepolisian atas tuduhan pencemaran nama baik, penodaan agama, dan acaman yang dilakukan netizen.

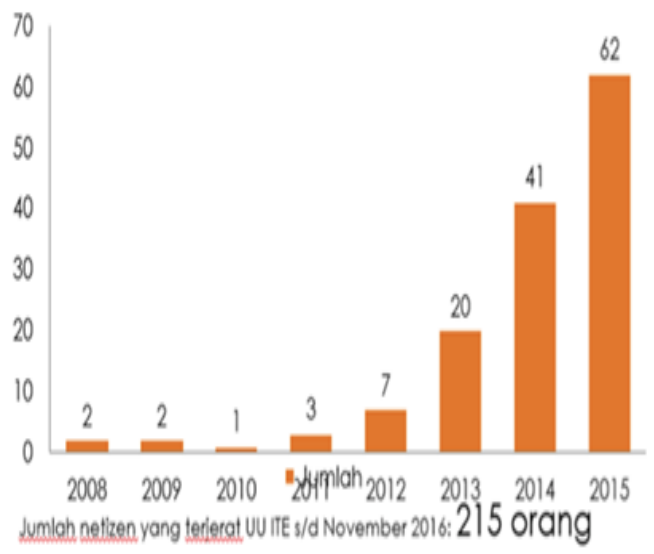

Gambar 1. Meningkatnya laporan ke Polisi terkait pencemaran nama baik, penodaan agama dan ancaman Sumber: (SAfeNet))

Atas dasar tersebut Tim Fikom Untar kembali mamaparkan bagaimana cara menggunakan teknologi komunikasi dan informasi khususnya sosial media untuk kegiatan yang positif. Tim Fikom Untar juga memberikan tips yang bermanfaat kepada mahasiswa
STAKN Manado jiga menemukan akunakun yang bernuansa provokasi atau mencemarkan nama baik atau ancaman seperti yang dipaparkan pada UU ITE pasal 27 dan pasal 28.

\section{LAPOR}

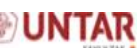

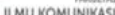

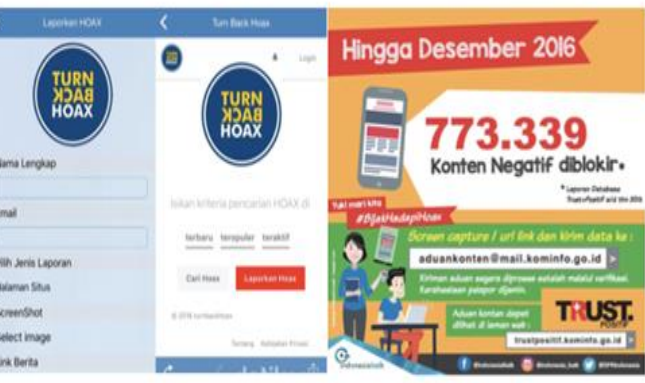

Gambar 2. Aplikasi pemerintah untuk menangani informasi yang melanggar UU ITE (Sumber (Sari \& Paramita, 2017)

Mahasiswa dapat melaporkannya melalui aplikasi yang telah diberikan pemerintah untuk mengantisipasi hal tersebut. Aplikasi androit atau IOS yang dikeluarkan oleh kepolisian yaitu "Trun Back Hoax". Selain itu Kementrian Komunikasi dan Informasi Republik Indonesia (Kominfo) juga mengeluarkan program "Trust Positif" yang digunakan untuk melapor akun-akun yang melanggar pasal 27 dan pasal 28 UU ITE dengan cara meng-copy link akun-akun tersebut dan membubuhkannya dalam halaman "Trun Back Hoax" atau "Trust Positif". Kedua aplikasi tersebut akan membaca dan menyelidiki secara digital. Jika benar terindikasi melanggar UU ITE maka akan secara otomatis akan menghapus akun-akun tersebut.

Dari penjelasan Tim Fikom Untar mahasiswa STAKN Manado nampak antusias dalam mengikuti kuliah umum tersebut. Berikut ini adalah suasan yang terjadi saat kuliah umum dilaksanakan. Dari hasil pengamatan mahasiswa yang datang dalam kegiatan tersebut kurang lebih berjumlah 250 mahasiswa 
dan dosen STAKN Manado yang mengikuti kuliah umum tersebut.

Setelah itu, dilanjutkan dengan sesi diskusi dan juga tanya jawab dengan peserta. Pada sesi diskusi dan tanya jawab ini, peserta tampak antusias terhadap materi yang telah diberikan oleh tim. Hal ini dapat dilihat dengan banyaknya jumlah penanya, bahkan penanya tidak hanya berasal dari kalangan mahasiswa/mahasiswi tetapi para staf pengajar lainnya juga ikut berpartisipasi dengan memberikan pertanyaan. Sampai akhir waktu dari sesi ini, peserta masih tampak aktif dengan pertanyaan-pertanyaan. Kemudian, setiap penanya juga mendapatkan goody bag yang telah dipersiapkan sebelumnya oleh tim. Karena jumlah goody bag yang terdapat, tim memutuskan bahwa sisa dari goody bag tersebut diserahkan kepada lembaga mahasiswa senat untuk diatur distribusinya. Berikut ini adalah gambar yang menunjukan antusiasme mahasiswa dan dosen STAKN Manado.

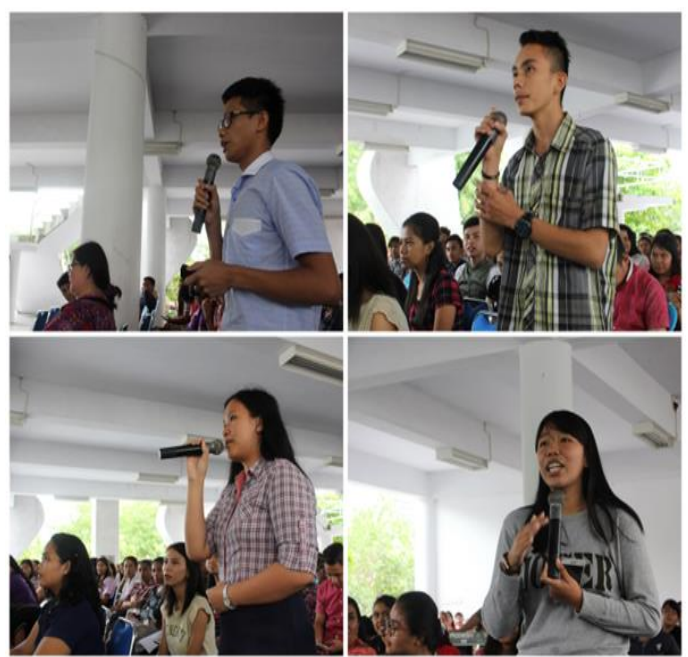

Gambar 3. Suasana diskusi mahasiswa STAKN Manado kepada Tim Fikom Untar.(Sumber: data pribadi)

Melalui kegiatan PKM ini juga terdapat banyak peserta yang menyatakan keluhannya mengenai banyaknya berita bohon atau HOAX yang mereka temui dalam sosial media dan bagaimana cara melaporkannya. Terdapat juga kasus dimana salah satu mahasiswi merasa dirinya telah dicemarkan nama baiknya melalui sebuah berita tidak benar, tetapi dirinya tidak paham bagaimana harus melaporkan hal tersebut. Pada kesempatan tersebut, tim juga memberikan contoh praktek tentang cara apa saja yang dapat digunakan untuk melaporkan bila menemui konten berita bohong atau HOAX, pornografi, atau konten-konten negatif lainnya di situs dan sosial media, misalnya melalui cara mengirimkan email pengaduan kepada depkominfo atau dengan mendownload aplikasi turn back hoax.

Diskusi dan tanya jawab dengan peserta dilanjutkan dengan pertanyaan tentang tanggapan dari sisi akademisi terkait permasalahan yang muncul akibat etika dan banyaknya berita bohong atau HOAX sekarang ini. Kemudian juga bagaimana hal tersebut dilihat dalam ranah ilmu komunikasi, kaitan antara teori dengan praktek pada dunia nyata.

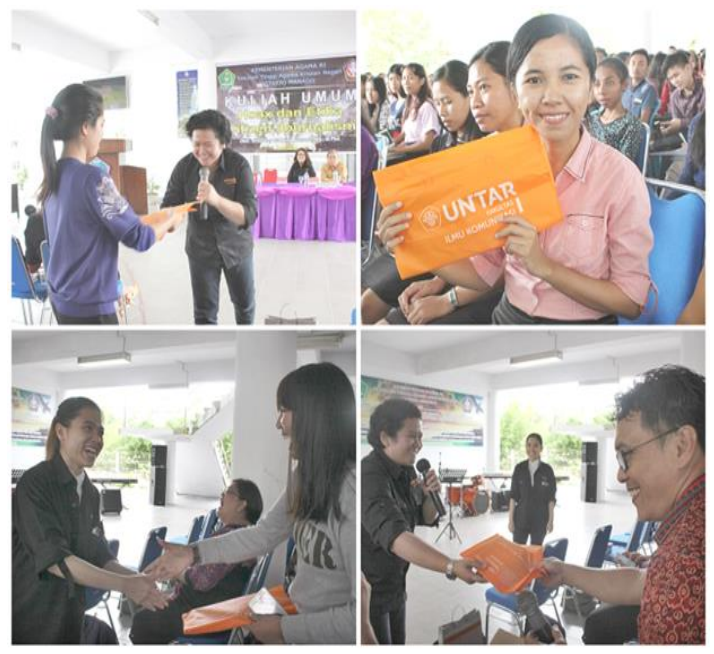

Gambar 4. Pemberian goody bag kepadan mahasiswa dan dosen STAKN Manado

(Sumber: data pribadi)

Tim juga menekankan pentingnya sikap berpikir secara kritis yang harus dimiliki oleh generasi muda saat ini dalam menghadapi setiap berita yang ditemui dalam sosial media dan media - 
media lainnya. Kemudian, pentingnya mengikuti etika dalam penggunaan sosial media karena hal tersebut dapat saja merugikan orang lain bahkan diri sendiri. Hal ini dapat dilihat dari banyaknya kasus pelanggaran hukum terkait dengan ketidakhati-hatian dalam menggunakan sosial media dan teknologi komunikasi lainnya.

Kegiatan PKM diakhiri dengan serah terima plakat dari pihak STAKN Manado kepada tim, yang dilanjutkan dengan foto bersama dengan seluruh peserta, baik mahasiswa maupun staf pengajar. Kemudian acara dilanjutkan dengan makan siang bersama antara tim dengan pimpinan dan staf pengajar dari STAKN Manado.

Pelaksanaan kegiatan PKM ini berhasil dan sukses, tetapi untuk dapat dikatakan sukses secara menyeluruh dan berhasil sebagai solusi atas permasalahan yang dihadapi oleh mitra maka harus dilakukan evaluasi dan monitoring atas kegiatan PKM ini. Evaluasi dan monitoring akan dilakukan tim dengan bantuan dari pihak mitra. Hal ini dikarenakan adanya keterbatasan yang dimiliki oleh tim, dimana tim tidak dapat berada dilokasi secara terus-menerus. Pihak mitra akan memberikan hasil evaluasi apakah metode ceramah dan penyuluhan yang diberikan oleh tim berhasil atau tidak, tepat atau tidak untuk memecahkan masalah yang dihadapi. Kegiatan evaluasi dan monitoring ini penting untuk dapat mengukur secara jelas dan pasti mengenai keberhasilan dari metode yang digunakan dan perbaikan ke depannya.

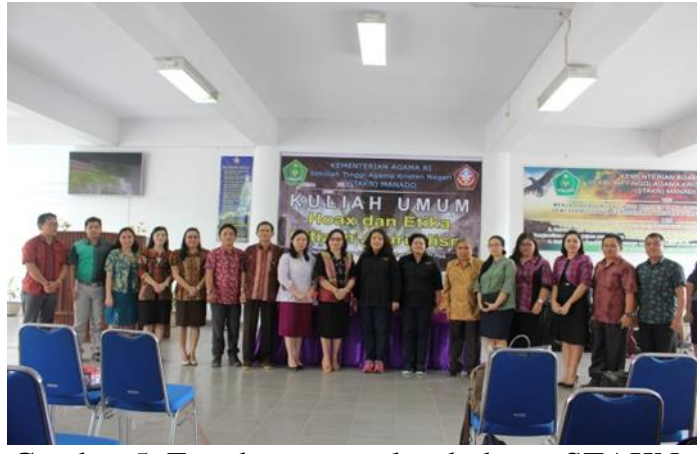

Gambar 5. Foto bersama seluruh dosen STAKN Manado dan Tim Fikom Untar(Sumber: data pribadi)

Atas keberhasilan dalam kegiatan ini, Tim Fikom Untar mengucapkan terimakasih kepada Direktorat Penelitian dan Pengabdian Kepada Masyarakat Universitas Tarumanagara yang telah mendukung kegiatan tersebut dana Sekolah Tinggi Agama Kristen Negara (STAKN) Manado yang telah memberikan kesempatan untuk melaksanakan kegaitan pengabdian kepada masyarakat (PKM) Tim Fikom Untar melalui kuliah umum.

\section{SIMPULAN}

Kesimpulan utama yang dapat diperoleh dalam kegiatan PKM ini adalah seluruh kegiatan berjalan dengan lancar dan sukses. Hal ini dapat dilihat dari banyaknya jumlah peserta yang mengikuti kegiatan PKM, dan antusiasme peserta dalam mengikuti kegiatan. Hal ini diluar dari perkiraan tim yang tidak menyangka akan menerima sambutan yang luar biasa. Kegiatan PKM ini menunjukkan keberhasilan tim dalam melakukan kerjasama dengan mitra dan menciptakan interaksi yang sinergi antara tim, mitra, dan khalayak. Selain itu, tema dan materi yang diberikan sesuai dan menarik bagi khalayak sasaran sehingga, peserta kegiatan PKM atau khalayak sasaran antusias dalam mengikuti kegiatan, hal ini dapat dilihat dengan 
banyaknya pertanyaan pada sesi diskusi dan tanya jawab. Hal terakhir mengenai evaluasi dan monitoring akan dilakukan tim dengan bantuan dan kerjasama dengan pihak mitra.

\section{DAFTAR PUSTAKA}

Anisa, R., \& Rachmaniar. (2016). Hoax Politik pada media sosial instagram studi etnografi virtual tentang keberadaan instaram dan hoax politik. Prosiding: Akselarasi Pembangunan Masyarakat Lokal Melalui Komunikasi Dan Teknologi Informasi. Diakses pada 18 Oktober 2017 Dari: http://jurnal.fisip.unila.ac.id/index .php/prosidingkom/article/view/28 1

(n.d.). Retrieved January 26, 2017, from SAfeNet: http://safenetvoice.org/

Gani, S. (n.d.). Apa itu Jurnalisme Warga? Retrieved Januari 20, 2017, from www.sloka.or.id: http://www.sloka.or.id/apa-itujurnalisme-warga/

Hartik, A. (2017, Januari 6). Menkominfo: Blokir Situs, Kami
Tak Lihat Bungkusnya, tetapi Kontennya. Retrieved Mei 31, 2017, from Kompas Online: http://regional.kompas.com/read/2 017/01/06/14260241/menkominfo .blokir.situs.kami.tak.lihat.bungku snya.tetapi.kontennya

Marketeers. (2017, 13 Juli). Persoalan Etika dalam Jurnalisme Online. Retrieved Mei 31, 2017, from Marketeers:

http://marketeers.com/persoalanetika-dalam-jurnalisme-online/

Paramita, S.., Azeharie, S., \& Sari, W.P. (2015). Literasi New Media Dalam Membangun Generasi Muda. Kaji Tindak: Jurnal Pemberdayaan Masyarakat, vol 2, No. 1, 69-75.

Sari, W. P., \& Paramita, S. (2017, April). Hoax dan Etika Citizen Journalism. Jakarta, DKI Jakarta, Indonesia.

Sebastian, L. (2016, 20 Januari). Awas Hoax! Kabar Tipuan yang Mematikan. Retrieved Oktober 18, 2017, From Detik Online: http://inet.detik.com/cyberlife/d3122471/awas-hoax-kabar-tipuanyang-mematikan 